\title{
Influence of nitrogen fertilization on chemical composition of cultivated nettle
}

\author{
Sanja Radman ${ }^{\text {, }}$, Ivanka Žutić1, Sanja Fabek1, Jana Šic Žlabur², Božidar Benko', Nina Toth', Lepomir Čoga ${ }^{3}$ \\ ${ }^{1}$ Department of Vegetable Crops, University of Zagreb Faculty of Agriculture, Svetošimunska Cesta 25, 10000 Zagreb, Croatia; ${ }^{2}$ Department of \\ Agricultural Technology, Storage and Transport, University of Zagreb Faculty of Agriculture, Svetošimunska Cesta 25, 10000 Zagreb, Croatia; \\ ${ }^{3}$ Department of Plant Nutrition, University of Zagreb Faculty of Agriculture, Svetošimunska Cesta 25, 10000 Zagreb, Croatia
}

\section{A B S T R A C T}

Stinging nettle (Urtica dioica L.) is a medicinal and edible plant species with a high economic potential. In most European countries nettle is still not produced commercially but is collected from natural habitats. This plant requires large amounts of nitrogen for its improved growth and satisfactory yield, which can result in accumulation of harmful nitrates and reducing of raw material quality. Mentioned problems can be solved by controlling the amount of nitrogen through fertilization, i.e. introduction of stinging nettle into agricultural production. The aim of this study was to determine the effect of three nitrogen fertilization doses $\left(0,100\right.$ and $\left.200 \mathrm{~kg} \mathrm{~N} \mathrm{ha}^{-1}\right)$ on the chemical composition of cultivated nettle in the second year of growing. The harvest of the nettle for consumption in fresh form was carried out before flowering and six harvests were performed. It was found that cultivated nettle is a valuable source of potassium $[2.27 \% \mathrm{~K}$ dry weight (dw)], calcium (5.21\% Ca dw) and

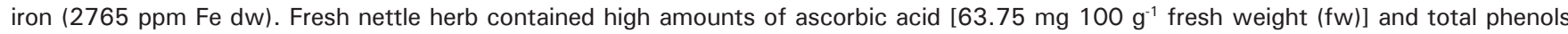
(732.49 mg GAE $100 \mathrm{~g} \mathrm{~g}^{-1} \mathrm{fw}$ ), correlated with its high antioxidant capacity (1936.58 $\mathrm{mM}^{-1}$ Trolox L $\mathrm{L}^{-1} \mathrm{fw}$ ). The highest nitrogen dose (200 kg $\mathrm{ha}^{-1}$ ) increased the content of crude protein and calcium, however resulted in higher nitrate content and lower values of dry matter, iron, total phenols and ascorbic acid. Therefore, fertilization with $100 \mathrm{~kg} \mathrm{~N} \mathrm{ha}^{-1}$ could be recommended in production of nettle with a high nutritional value.

Keywords: Harvest term; Mineral content; Bioactive compounds; Nitrophilous plant; Urtica dioica

\section{INTRODUCTION}

Stinging nettle (Urtica dioica L.), a perennial plant species from the Urticaceae family, is widely distributed throughout the temperate regions of the world (Bacci et al., 2009; Kaya and Aydin, 2009). All plant parts (stem, leaves, roots and seeds) are usable, therefore nettle is widely applied in medicine, biodynamic agriculture, food-, cosmetic-, textile- and the pharmaceutical industry (Di Virgilio et al., 2015). The healing properties of nettle are known for centuries and its hypoglycemic, anti-diabetic, anti-inflammatory, antireumatic, hypotensive, antioxidant, antimicrobial, analgesic and antiulcer activity has been proven more recently (Gülçin et al., 2004; Yildiz et al., 2008; Ahangarpour et al., 2012; Upton, 2013). Multidirectional therapeutic activity of this valuable plant is a result of its rich chemical composition (Biesiada et al., 2009). Namely, fresh or processed nettle is a high-protein and low-calorie source of essential nutrients, minerals, vitamins (Rutto et al., 2013), especially vitamin C (Skalozubova and Reshetova, 2013), and other valuable bioactive compounds such as carotenoids and polyphenols (Biesiada et al., 2010). It is known that phenols have a preventive role in the development of cancer and heart diseases (Kähkönen et al., 1999) due to their antioxidant behavior (Özkan et al., 2011). So far numerous studies have been conducted with wild nettle (Guil-Guerrero et al., 2003; Gülçin et al., 2004; Ozyurt et al., 2007; Özkan et al., 2011; Kukrić et al., 2012; Otles and Yalcin, 2012; Andualem et al. 2015), however in recent years interest about cultivated nettle is also increasing (Biesiada and Wołoszczak 2007; Grevsen et al., 2008; Biesiada et al., 2009). The reason for such trend is the raising concern about health, since the wild plant material collected from natural habitats may be of questionable nutritional and medicinal value. For example, nettle leaves picked in ecological protected areas had significant higher total phenol content and antioxidant capacity than plants from more polluted areas (Koczka et al., 2015). Bisht et al. (2012) state that stinging nettle prefers to grow on loose soil with organic matter rich in nitrogen and with a high phosphate levels for its rapid growth. Although nitrogen

\footnotetext{
*Corresponding author:

Sanja Radman, Department of Vegetable Crops, University of Zagreb Faculty of Agriculture, Svetošimunska Cesta 25, 10000 Zagreb, Croatia. E-mail: sradman@agr.hr

Received: 14 April 2015; $\quad$ Revised: 16 December 2015; $\quad$ Accepted: 19 December 2015; $\quad$ Published Online: 19 December 2015
} 
strongly stimulates growth and is the most important element in stinging nettle nutrition (Rutto et al., 2012), its excessive adoption can result in accumulation of potentially harmful nitrates in plants. Nitrates are part of the nitrogen cycle and have an important role in the nutrition and function of plants (Shimada and Ko, 2004; EFSA, 2008). However, very high concentrations can increase the occurrence of methaemoglobinemia and possibly gastric cancer (CárdenasNavarro et al. 1999). According to Santamaria (2006) nitrate accumulation in plants is affected by the following factors: genetic, environmental (atmospheric humidity, substrate water content, temperature, irradiance, photoperiod) and agricultural (nitrogen doses and chemical forms, availability of other nutrients, use of herbicides). Previous studies on cultivated nettle have shown that nutritional quality and chemical composition of the plants can be affected by the age of plantation, harvest time (Biesiada et al., 2010) and nitrogen fertilization (Biesiada et al., 2009; Rutto et al., 2012).

There are no results about the chemical composition of cultivated nettle grown in continental part of Croatia. Therefore, the aim of this study was to determine the influence of three levels of nitrogen fertilization $(0,100$, $200 \mathrm{~kg} \mathrm{~N} \mathrm{ha}^{-1}$ ) on the content of some minerals (potassium, calcium, iron), crude protein and bioactive compounds (antioxidant capacity, total phenols and ascorbic acid) in cultivated nettle during multiple harvests.

\section{MATERIALS AND METHODS}

\section{Field experiment and plant material}

The field experiment was set up in Zagreb, Croatia (45 $49^{\prime}$ $\left.\mathrm{N}, 16^{\circ} 02^{\prime} \mathrm{E}\right)$. Sowing of U. dioica seed (B\&T World Trade, France) in unheated greenhouse was conducted on March 4, 2013, in polystyrene trays with 209 cells and seedlings were planted in the open field on April 15, 2013. Spacing was $0.5 \times 0.3 \mathrm{~m}$, which made 6.6 plants $\mathrm{m}^{-2}$. The basic trial plot had $8.75 \mathrm{~m}^{2}$ (length $3.5 \mathrm{~m}$; width $2.5 \mathrm{~m}$ ) and included 48 plants, 4 rows with 12 plants. In the second year of nettle growing, in 2014, three levels of nitrogen fertilizations $(0$, 100 and $200 \mathrm{~kg} \mathrm{ha}^{-1}$ ) were tested. The monofactorial field trial was arranged in a randomized block design with four replications. Fertilization was applied in the form of calcium ammonium nitrate $(27 \% \mathrm{~N}$, Petrokemija, Croatia) given as a split application: half dose of nitrogen fertilizer was added in the beginning of vegetation and the remaining amount was divided into two parts and given in intervals of 40 days. Harvest was done before flowering, because final product was nettle for fresh consumption, i.e. for the food industry. First harvest of two year old nettle plants started on April 14 and continued on May 12, June 13, July 9, August 7 and September 18. Therefore, periods between harvests lasted 28, 32, 26, 29 and 42 days. Representative samples (20 plants from each plot) after each harvest were prepared by separating leaves and young apical parts from stems. In these samples content of dry matter, crude protein, potassium, calcium and iron were determined and expressed on dry weight basis (dw). Ascorbic acid, total phenols, antioxidant capacity and content of nitrates were expressed on a fresh weight basis (fw).

\section{Meteorological conditions}

During stinging nettle growing period in 2014 mean, minimum and maximum air temperatures and sum of precipitation per decades were measured (Fig 1). The beginning of vegetation was recorded in the second half of March, when the average daily air temperature increased to $11.4^{\circ} \mathrm{C}$. From March to the first week of August the mean daily temperature values increased linearly, with the exception of April and May. In the second decade of April decrease in temperature was recorded, i.e. minimum temperature amounted $5.4^{\circ} \mathrm{C}$. However, in third decade of this month temperature increased and average mean value was $15.0^{\circ} \mathrm{C}$. The second temperature decrease occurred in first two decades of May.

Between the first and the last harvest (from April 14 to September 18) values of mean daily air temperatures ranged between 10.8 and $23.1^{\circ} \mathrm{C}$. Radman et al. (2014) stated that optimal temperatures for stinging nettle growth are between 15 and $25^{\circ} \mathrm{C}$. Such temperatures were recorded during June and in the first decade of July (20.2, 20.3 and $20.2^{\circ} \mathrm{C}$ in June, and $20.7^{\circ} \mathrm{C}$ in the first half of July). The optimal temperatures and sufficient amounts of precipitation during this period (5.0, 42.1, 99.9, and $14.9 \mathrm{~mm}$ ) resulted in the shortest period of vegetation between the third and fourth harvest ( 26 days).

From the beginning of vegetation until the last harvest (from March till September) approximately $877.0 \mathrm{~mm}$ of rainfall was recorded, wherein the rainiest month was September with $178.6 \mathrm{~mm}$ of precipitation.

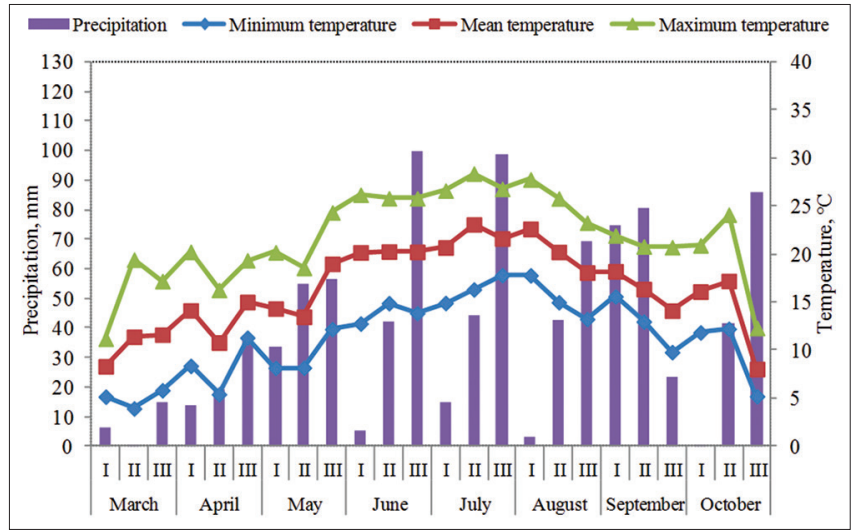

Fig 1. Average temperatures and total precipitation in the vegetation period of stinging nettle in Zagreb, 2014. 


\section{Determination of minerals and nitrate content in nettle herb}

After each harvest the samples of plant material were dried at $105^{\circ} \mathrm{C}$, milled, homogenized and then analyzed in the Analytical Laboratory of the Department of Plant Nutrition at Faculty of Agriculture, Zagreb. Potassium was determined by a flame photometer (Jenway, model PEP7, Great Britain, 2006), calcium and iron by an atomic absorption spectrophotometer (Thermo Scientific, model M Series AA Spectrometer, China, 2008) according to the AOAC method (1995) after digestion with concentrated $\mathrm{HNO}_{3}$ (Milestone 1200 Mega Microwave Digester). Nitrogen was determined by dry combustion method (HRN ISO 13878, 2004), and content of crude protein was calculated according to the formula: $\% \mathrm{~N} \times 6.25$ (Vajić, 1964). Gravimetric method (HRN ISO 11465, 2004) was used to determine the dry content in plants. Nitrate content was determined in fresh plant samples by HRN ISO method 10304-1:1998. All analyses were made in triplicate. Content of dry matter, crude protein and minerals were expressed in $\% \mathrm{dw}$, while nitrates were expressed in $\mathrm{mg}$ $\mathrm{NO}_{3} \mathrm{~kg}^{-1}$ fw.

\section{Determination of total phenolic content of fresh nettle leaves}

Total phenolic content of fresh stinging nettle leaves was obtained by Ough and Amerine method (1988). Plant sample of $10 \mathrm{~g}( \pm 0.01 \mathrm{~g})$ was homogenized with $40 \mathrm{ml}$ of $80 \%$ ethanol and was boiled for 10 minutes to reflux. The extract of nettle leaves was filtered in a volumetric flask volume of $100 \mathrm{ml}$. The reside together with the filter paper and a $50 \mathrm{ml}$ of $80 \%$ ethanol was transferred in a flask and then boiled to reflux for $10 \mathrm{~min}$. The obtained extract was combined with the previously and flask was filled up to volume with $80 \%$ ethanol. After extraction, the FolinCiocalteu reaction was carried out as follows: in a $50 \mathrm{ml}$ volumetric flask $0.5 \mathrm{ml}$ of the extract was pipetted, then $30 \mathrm{~mL}$ of distilled water and $2.5 \mathrm{ml}$ of Folin-Ciocalteu reagent diluted with distilled water (1:2) was added. $7.5 \mathrm{ml}$ of saturated sodium carbonate was added to the prepared mixture. Flask was filled with distilled water to the mark and left to stand for two hours at room temperature. Thereafter, the absorbance of the solution was measured at $750 \mathrm{~nm}$ by spectrophotometer (Shimadzu UV 1650 PC, USA) using distilled water as a blank test. As external standard gallic acid was used and the concentrations of samples were expressed according to data from calibration curve $(y=0.001 x+0.0148)$. The final amount of total phenols was expressed as mg GAE $100 \mathrm{~g}^{-1}$ of fresh weight (fw).

\section{Antioxidant capacity (ABTS method) of fresh plant material}

The antioxidant capacity in samples of fresh leaves was performed by ABTS method (Miller et al., 1993;
Re et al., 1999). $2.5 \mathrm{mM}$ of Trolox (6-hydroxy2,5,7,8-tetramethylchroman-2-carboxylic acid; SigmaAldrich) was prepared in ethanol $(80 \%)$ for use as a stock standard. ABTS, 2,2'-azinobis (3-ethylbenzothiazoline-6sulfonic acid) and potassium persulfate were obtained from Sigma-Aldrich. ABTS $(7 \mathrm{mM})$ and potassium persulfate $(140 \mathrm{mM})$ were dissolved in distilled water. These two prepared solutions were mixed: $88 \mu \mathrm{L}$ potassium persulfate $(140 \mathrm{mM})$ and $5 \mathrm{ml} \mathrm{ABTS}$ solution and the mixture was left in the dark at room temperature for $16 \mathrm{~h}$ before use in order to produce ABTS radical (ABTS $\bullet+)$. On the day of analysis $1 \%$ ABTS $\bullet+$ solution $(1 \mathrm{~mL} \mathrm{ABTS} \bullet+$ in volumetric flask of $100 \mathrm{~mL}$ filled with $96 \%$ ethanol to the mark) was prepared. The absorbance of ABTS radical solution was measured at $734 \mathrm{~nm}$ and set to $0.70 \pm 0.02 .160 \mu \mathrm{L}$ of obtained ethanol extracts were directly injected in the cuvette, mixed with $2 \mathrm{~mL} \mathrm{1 \%} \mathrm{ABTS \bullet +,} \mathrm{and} \mathrm{absorbance} \mathrm{at}$ $734 \mathrm{~nm}$ was measured. Antioxidant capacity in the nettle samples were expressed as $\mathrm{mM}$ Trolox $\mathrm{L}^{-1} \mathrm{fw}$.

\section{Ascorbic acid (Vitamin C) determination of plant material}

Ascorbic acid was determined according to the AOAC method (2002). The method is based on titration with 2,6-dichlorophenolindophenol to the appearance of pink color, which must be stable for at least five seconds. The reagent 2,6-p-dichlorophenolindophenol oxidizes L-ascorbic acid in dehydroascorbic acid, while color reagent turns into colorless leucobasis. Plant sample (10 g $\pm 0.01 \mathrm{~g})$ was homogenized with $2 \%$ solution of oxalic acid $(\mathrm{v} / \mathrm{v})$ and quantitatively transferred to a volumetric flask of $100 \mathrm{ml}$. After one hour and with occasional stirring, the flask was filled up with a $2 \%$ oxalic acid (v/v) to the mark and filtered. The filtrate was than titrated with a solution of 2,6-dichlorophenolindophenol to the appereance of pink color. The amount of vitamin $C$ in the sample was expressed as mg $100 \mathrm{~g}^{-1} \mathrm{fw}$.

\section{Statistical analysis}

For statistical analysis of the data statistical program SAS ${ }^{\circledR}$ Software v. 9.3 (2010) was used and the samples were analyzed separately for each harvest. Analysis of variance was performed to determine the influence of nitrogen fertilization at the significance level $\mathrm{p} \leq 0.05$ and $\mathrm{p} \leq 0.01$.

\section{RESULTS AND DISCUSSION}

\section{Dry matter content}

Dry matter content defines the quality of raw materials, so higher values represent larger amounts of vitamins, minerals and other valuable compounds. Its allocation in plants is affected by mineral nutrition and can be managed by adequate fertilization (Rutto et al., 2012). In this research dry 
Radman, et al.: Chemical composition of cultivated nettle

\begin{tabular}{|c|c|c|c|c|c|c|}
\hline Harvest & Fertilization & Dry matter & Crude protein & Potassium & Calcium & Iron \\
\hline & kg N ha-1 & $\%$ & $\% d w$ & $\% \mathbf{K ~ d w}$ & $\% \mathrm{Ca}$ dw & ppm Fe dw \\
\hline \multirow[t]{5}{*}{ First } & 0 & $24.07 \pm 0.19^{A *}$ & $22.00 \pm 0.44^{c}$ & $2.20 \pm 0.06^{A B}$ & $4.77 \pm 0.09^{B}$ & $1625 \pm 9^{A}$ \\
\hline & 100 & $21.10 \pm 0.14^{\mathrm{B}}$ & $27.69 \pm 0.25^{\mathrm{B}}$ & $2.47 \pm 0.09^{A}$ & $6.29 \pm 0.11^{\mathrm{A}}$ & $1120 \pm 7^{B}$ \\
\hline & 200 & $20.91 \pm 0.16^{C}$ & $29.81 \pm 0.38^{A}$ & $1.93 \pm 0.07^{B}$ & $6.20 \pm 0.10^{A}$ & $931 \pm 5^{c}$ \\
\hline & $\bar{\chi}$ & 22.03 & 26.50 & 2.20 & 5.75 & 1225 \\
\hline & LSD & 0.711 & 1.106 & 0.319 & 0.423 & 28.46 \\
\hline \multirow[t]{5}{*}{ Second } & 0 & $24.80 \pm 0.11^{\mathrm{A}}$ & $21.81 \pm 0.31^{\mathrm{C}}$ & $2.20 \pm 0.05^{\mathrm{B}}$ & $4.71 \pm 0.15^{\mathrm{B}}$ & $5030 \pm 11^{A}$ \\
\hline & 100 & $21.72 \pm 0.12^{\mathrm{B}}$ & $24.63 \pm 0.25^{\mathrm{B}}$ & $2.49 \pm 0.04^{\mathrm{A}}$ & $4.97 \pm 0.10^{\mathrm{B}}$ & $2869 \pm 15^{B}$ \\
\hline & 200 & $21.35 \pm 0.13^{\mathrm{B}}$ & $29.25 \pm 0.13^{A}$ & $2.20 \pm 0.07^{B}$ & $5.98 \pm 0.11^{A}$ & $1010 \pm 14^{c}$ \\
\hline & $\bar{\chi}$ & 22.62 & 25.23 & 2.30 & 5.22 & 2969 \\
\hline & LSD & 0.532 & 0.732 & 0.250 & 0.518 & 59.08 \\
\hline \multirow[t]{5}{*}{ Third } & 0 & $25.30 \pm 0.13^{A}$ & $16.69 \pm 0.31^{c}$ & $1.83 \pm 0.03^{\mathrm{B}}$ & $4.50 \pm 0.09^{\mathrm{B}}$ & $11495 \pm 15^{\mathrm{A}}$ \\
\hline & 100 & $23.48 \pm 0.12^{\mathrm{C}}$ & $22.56 \pm 0.19^{\mathrm{B}}$ & $2.20 \pm 0.06^{A}$ & $4.82 \pm 0.07^{\mathrm{B}}$ & $9915 \pm 13^{B}$ \\
\hline & 200 & $24.21 \pm 0.10^{\mathrm{B}}$ & $27.94 \pm 0.25^{A}$ & $1.99 \pm 0.04^{\mathrm{B}}$ & $5.69 \pm 0.08^{A}$ & $5866 \pm 12^{C}$ \\
\hline & $\bar{\chi}$ & 24.33 & 22.40 & 2.01 & 5.00 & 9092 \\
\hline & LSD & 0.052 & 0.771 & 0.177 & 0.349 & 59.72 \\
\hline \multirow[t]{5}{*}{ Fourth } & 0 & $28.10 \pm 0.10^{A}$ & $17.31 \pm 0.13^{\mathrm{B}}$ & $2.57 \pm 0.05^{b}$ & $4.30 \pm 0.07^{c}$ & $1458 \pm 9^{A}$ \\
\hline & 100 & $23.20 \pm 0.12^{\mathrm{B}}$ & $22.81 \pm 0.25^{A}$ & $2.77 \pm 0.06^{a}$ & $4.94 \pm 0.08^{\mathrm{B}}$ & $1080 \pm 11^{B}$ \\
\hline & 200 & $22.90 \pm 0.13^{\mathrm{B}}$ & $23.50 \pm 0.31^{A}$ & $2.49 \pm 0.07^{b}$ & $5.89 \pm 0.06^{A}$ & $919 \pm 10^{C}$ \\
\hline & $\bar{\chi}$ & 24.73 & 21.21 & 2.61 & 5.04 & 1152 \\
\hline & LSD & 0.522 & 0.733 & 0.164 & 0.310 & 44.53 \\
\hline \multirow[t]{5}{*}{ Fifth } & 0 & $27.60 \pm 0.09^{B}$ & $16.94 \pm 0.31^{\mathrm{B}}$ & $2.27 \pm 0.03^{\mathrm{B}}$ & $4.71 \pm 0.06^{b}$ & $1577 \pm 13^{A}$ \\
\hline & 100 & $23.10 \pm 0.10^{C}$ & $22.88 \pm 0.19^{A}$ & $2.64 \pm 0.01^{\mathrm{A}}$ & $5.02 \pm 0.09^{a}$ & $1245 \pm 12^{B}$ \\
\hline & 200 & $28.60 \pm 0.11^{\mathrm{A}}$ & $23.25 \pm 0.25^{A}$ & $2.36 \pm 0.05^{\mathrm{B}}$ & $5.10 \pm 0.07^{a}$ & $766 \pm 14^{c}$ \\
\hline & $\bar{\chi}$ & 26.43 & 21.02 & 2.42 & 4.94 & 1196 \\
\hline & LSD & 0.445 & 0.772 & 0.156 & 0.203 & 57.55 \\
\hline \multirow[t]{6}{*}{ Sixth } & 0 & $28.90 \pm 0.13^{A}$ & $16.69 \pm 0.31^{c}$ & $1.88 \pm 0.04^{\mathrm{B}}$ & $4.66 \pm 0.07^{B}$ & $1445 \pm 12^{A}$ \\
\hline & 100 & $21.10 \pm 0.11^{\mathrm{B}}$ & $19.44 \pm 0.19^{\mathrm{B}}$ & $2.27 \pm 0.03^{A}$ & $5.55 \pm 0.06^{A}$ & $934 \pm 9^{B}$ \\
\hline & 200 & $18.40 \pm 0.15^{C}$ & $21.69 \pm 0.25^{A}$ & $2.16 \pm 0.02^{A}$ & $5.60 \pm 0.04^{A}$ & $501 \pm 8^{C}$ \\
\hline & $\bar{\chi}$ & 22.80 & 19.27 & 2.10 & 5.27 & 960 \\
\hline & LSD & 0.587 & 0.779 & 0.142 & 0.263 & 44.53 \\
\hline & 0 & 26.46 & 18.57 & 2.16 & 4.61 & 3771 \\
\hline \multirow[t]{2}{*}{ Average } & 100 & 22.28 & 23.33 & 2.47 & 5.27 & 2860 \\
\hline & 200 & 22.73 & 25.91 & 2.19 & 5.74 & 1665 \\
\hline Average & & 23.82 & 22.60 & 2.27 & 5.21 & 2765 \\
\hline
\end{tabular}

${ }^{*}$ Mean values $\pm S D$ followed by the same letter within each column do not differ significantly at $p \leq 0.05$ (a) and $p \leq 0.01$ (A) according to the LSD test

matter content ranged from 18.40 to $28.90 \%$, whereby both values were determined in the last harvest, at 200 and $0 \mathrm{~kg} \mathrm{~N}$ ha ${ }^{-1}$, respectively (Table 1). In each harvest the highest values occurred at $0 \mathrm{~kg} \mathrm{~N} \mathrm{ha}{ }^{-1}$ (from 24.07 to $28.90 \%$ ), meaning that the nitrogen fertilization had a negative impact on the dry matter content. The exception was the fifth harvest when the maximum value was achieved at the highest dose of nitrogen $\left(28.60 \%\right.$ at $\left.200 \mathrm{~kg} \mathrm{~N} \mathrm{ha}^{-1}\right)$. This negative correlation of dry matter content and nitrogen application has been confirmed in other studies. According to Grevsen et al. (2008) the value of dry matter decreases from $23.5 \%$ at $0 \mathrm{~kg} \mathrm{~N}$ ha ${ }^{-1}$ to $21 \%$ at $400 \mathrm{~kg} \mathrm{~N} \mathrm{ha}^{-1}$. Conversely, Weiss (1993) claims that increasing in nitrogen fertilization results in a significant increase of dry matter in leaves and stems. Regardless of the nitrogen fertilization, the dry matter content increased with number of harvests. The lowest average content of dry matter was recorded after the first harvest $(22.02 \%)$ and the highest after the fifth harvest (26.43\%). Accordingly, Grevsen et al. (2008) and Andualem et al. (2015) indicate that dry matter content of nettle mature leaves is higher compared to younger leaves. Contrary, Biesiada et al. (2010) claim that the leaves of stinging nettle, harvested in September, contained the lowest value of dry matter $(25.71 \%)$, while the highest amount was obtained from earlier harvest in May $(28.79 \%)$.

\section{Content of crude protein and minerals}

Crude protein content varied from 16.69 to $29.81 \%$ in dry weight $(\mathrm{dw})$ depending on harvest period, which is shown in Table 1. Contrary to the dry matter content, nitrogen fertilization increased the content of crude protein in all six harvests and the highest values were recorded when $200 \mathrm{~kg} \mathrm{~N}^{-1}$ was applied (from 21.69 to $29.81 \% \mathrm{dw}$ ). This trend was expected because higher 
values of nitrogen implicate higher content of crude protein, which is important for nutritive quality of plants (Fabek et al., 2012). Accordingly, the lowest values were determined in the absence of fertilization (from 16.69 to $22.00 \% \mathrm{dw}$ at $0 \mathrm{~kg} \mathrm{~N} \mathrm{ha}{ }^{-1}$ ). With subsequent cuts, crude protein content decreased and the highest average value was recorded after the first harvest $(26.50 \% \mathrm{dw})$, while the lowest after the last harvest $(19.27 \% \mathrm{dw})$. In accordance with this, Andualem et al. (2015) claim that the highest value of crude protein was recorded at early stage of flowering compared to mid and late stage. Again this pattern contradicts Biesiada et al. (2010), who stated that with higher number of harvests crude protein content increased from 17.31 to $21.43 \% \mathrm{dw}$.

The content of potassium ranged from 1.83 to $2.77 \% \mathrm{~K}$ $\mathrm{dw}$. The lowest value was recorded in third harvest at $0 \mathrm{~kg}$ $\mathrm{N} \mathrm{ha}^{-1}$ and the highest at fourth harvest at $100 \mathrm{~kg} \mathrm{~N} \mathrm{ha}{ }^{-1}$. Significantly higher amounts of potassium in all harvests were determined at $100 \mathrm{~kg} \mathrm{~N} \mathrm{ha}^{-1}$, while the highest dose of nitrogen had a negative effect on the potassium content. Regardless of the nitrogen fertilization, the lowest average value of potassium was recorded after the third harvest $(2.01 \% \mathrm{~K} \mathrm{dw})$ and the highest after the fourth harvest (2.61\% K dw). According to Bergmann (1992), potassium uptake by plants depends largely on diffusion and mass flux, meaning that its availability is severely reduced in dry periods. Plants may consequently exhibit signs of potassium deficiency after long dry periods even on soils with a good potassium status. In the period until the third harvest only $283.5 \mathrm{~mm}$ of precipitation occurred. It was about $46 \%$ less than in the period ranging between the third and the sixth harvest $(528.2 \mathrm{~mm})$.

Calcium content varied from 4.30 to $6.29 \% \mathrm{Ca} \mathrm{dw}$, and was higher than values reported by Biesiada et al. (2010). Higher dose of nitrogen fertilization had a positive effect on the content of this mineral, so the highest amount of calcium (from 5.10 to $6.20 \% \mathrm{Ca} \mathrm{dw}$ ) was determined by applying $200 \mathrm{~kg} \mathrm{~N} \mathrm{ha}{ }^{-1}$. Congruently, Bergmann (2010) points out that calcium mobility after nitrogen fertilization increased. Also, high concentration of calcium inhibits the uptake of other non-essential ions, especially heavy metals. Regardless of the fertilization, the highest value of calcium in this research was determined after the first harvest (5.75\% $\mathrm{Ca} \mathrm{dw})$ and the lowest after the fifth $(4.94 \% \mathrm{Ca} \mathrm{dw})$. It can be concluded that higher number of harvests had a negative influence on the content of calcium in stinging nettle. According to Biesiada et al. (2010), the amounts of potassium and calcium, in the second year of stinging nettle growth, decreased progressively with an increasing number of harvests. Nevertheless, calcium, potassium and iron levels are more influenced by meteorological factors than subsequent cuts.
In this research the content of iron in dry weight varied from 501 ppm (sixth harvest at $200 \mathrm{~kg} \mathrm{~N} \mathrm{ha}^{-1}$ ) to $11495 \mathrm{ppm}$ (third harvest at $0 \mathrm{~kg} \mathrm{~N} \mathrm{ha}^{-1}$ ). Nitrogen application had an adverse effect on iron content, and therefore the maximum values of this microelement were recorded at $0 \mathrm{~kg} \mathrm{~N} \mathrm{ha}{ }^{-1}$ (from 1445 to $11495 \mathrm{ppm} \mathrm{Fe} \mathrm{dw).} \mathrm{The} \mathrm{average} \mathrm{value} \mathrm{of}$ iron after all six harvests amounted $2765 \mathrm{ppm}$ Fe dw, which was a much higher value than data reported by Başgel and Erdemoğlu (2006) and Rutto et al. (2013), (98\% and 70\%, respectively).

High content of iron and potassium in nettle can be result of high levels of these minerals in the soil. According to the results of chemical analysis (data not shown) soil was rich supplied with iron (41310 $\mathrm{mg} \mathrm{kg}^{-1} \mathrm{Fe}$ ), while the amount

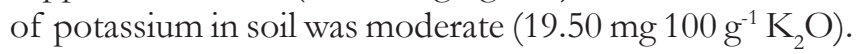
Although soil was poorly supplied with total nitrogen $(0.09 \% \mathrm{~N})$, high content of this mineral in plants can be explained by the positive effect of the nitrogen fertilization used in this research.

\section{Nitrate content}

Nitrate content in the stinging nettle leaves was high and varied from 849 (third harvest at $0 \mathrm{~kg} \mathrm{~N} \mathrm{ha}^{-1}$ ) to $1631 \mathrm{mg}$ $\mathrm{kg}^{-1}$ (first harvest at $200 \mathrm{~kg} \mathrm{~N} \mathrm{ha}^{-1}$ ) of fresh weight (fw), which is shown in Table 2. Namely, leafy vegetables have relatively high levels of nitrate, and for example, rucola can contains $4800 \mathrm{mg} \mathrm{kg}^{-1} \mathrm{fw}$, lamb's lettuce $2130 \mathrm{mg} \mathrm{kg}^{-1} \mathrm{fw}$ and spinach $785 \mathrm{mg} \mathrm{kg}^{-1} \mathrm{fw}$ (EFSA, 2008).

The highest rate of nitrogen $\left(200 \mathrm{~kg} \mathrm{~N} \mathrm{ha}^{-1}\right)$ resulted in more intensive nitrate accumulation (from 1145 to $1631 \mathrm{mg} \mathrm{kg}^{-1} \mathrm{fw}$ ). Regardless of the fertilization, the highest content of nitrate prevailed after first harvest $\left(1368 \mathrm{mg} \mathrm{kg}^{-1} \mathrm{fw}\right)$ and the lowest level after the third harvest $\left(1009 \mathrm{mg} \mathrm{kg}^{-1} \mathrm{fw}\right)$. This trend was unexpected since the nitrates are mostly transported towards plants by mass flow (Ćustić et al., 2003, according to Mengel and Kirkby, 2001), and until the first harvest the lowest amount of precipitation occurred $(54.0 \mathrm{~mm})$.

\section{Antioxidant capacity, total phenols and ascorbic acid determined in nettle}

Ascorbic acid and phenols, especially flavonoids, are the main antioxidants that neutralize free radicals in the human organism (Podsędek, 2007). In this research, antioxidant capacity of nettle (Table 2) varied from 1504.00 to 2149.91 $\mathrm{mM}$ Trolox $\mathrm{L}^{-1}(\mathrm{fw})$. There was no significant influence of nitrogen fertilization on antioxidant capacity in the first, second and fourth harvest. However, significantly higher antioxidant capacity in the remaining harvests (third, fifth and sixth) was recorded when $100 \mathrm{~kg} \mathrm{~N} \mathrm{ha}^{-1}$ was applied. From the above, it can be concluded that the impact of nitrogen fertilization on the antioxidant 
Radman, et al.: Chemical composition of cultivated nettle

Table 2: Effect of nitrogen fertilization on nitrate content, antioxidant capacity, total phenolic compounds and ascorbic acid, expressed in fresh weight (fw)

\begin{tabular}{|c|c|c|c|c|c|}
\hline Harvest & $\begin{array}{c}\text { Fertilization } \\
\text { kg N ha }^{-1}\end{array}$ & $\begin{array}{c}\text { Nitrate content } \\
\mathrm{mg} \mathrm{kg}^{-1} \mathrm{fw} \\
\end{array}$ & $\begin{array}{c}\text { Antioxidant capacity } \\
\mathrm{mM} \text { Trolox } \mathrm{L}^{-1} \mathrm{fw}\end{array}$ & $\begin{array}{c}\text { Total phenols } \\
\text { mg GAE } 100 \mathrm{~g}^{-1} \mathrm{fw} \\
\end{array}$ & $\begin{array}{l}\text { Ascorbic acid } \\
{\mathrm{mg} 100 \mathrm{~g}^{-1} \mathrm{fw}}\end{array}$ \\
\hline \multirow[t]{5}{*}{ First } & 0 & $982 \pm 6.00^{c *}$ & $2089.18 \pm 10.57$ & $881.48 \pm 0.77^{A}$ & $48.82 \pm 1.04^{\mathrm{A}}$ \\
\hline & 100 & $1492 \pm 8.00^{\mathrm{B}}$ & $2092.56 \pm 0.18$ & $689.00 \pm 1.15^{\mathrm{C}}$ & $24.93 \pm 2.08^{c}$ \\
\hline & 200 & $1631 \pm 12.00^{A}$ & $2089.63 \pm 14.62$ & $767.61 \pm 1.21^{\mathrm{B}}$ & $36.35 \pm 1.04^{\mathrm{B}}$ \\
\hline & $\bar{\chi}$ & 1368 & 2090.46 & 779.36 & 36.70 \\
\hline & LSD & 44.41 & NS & 0.909 & 5.960 \\
\hline \multirow[t]{5}{*}{ Second } & 0 & $920 \pm 9.00^{c}$ & $1946.36 \pm 38.69$ & $938.64 \pm 0.96^{A}$ & $111.00 \pm 1.00^{A}$ \\
\hline & 100 & $1347 \pm 14.00^{\mathrm{B}}$ & $1956.70 \pm 5.85$ & $695.70 \pm 0.19^{c}$ & $30.00 \pm 2.00^{B}$ \\
\hline & 200 & $1426 \pm 13.00^{A}$ & $1960.53 \pm 31.26$ & $700.17 \pm 0.57^{B}$ & $16.00 \pm 1.00^{C}$ \\
\hline & $\bar{\chi}$ & 1231 & 1954.53 & 778.17 & 52.33 \\
\hline & LSD & 54.78 & NS & 1.441 & 5.742 \\
\hline \multirow[t]{5}{*}{ Third } & 0 & $849 \pm 5.00^{c}$ & $2077.26 \pm 9.00^{\mathrm{AB}}$ & $572.65 \pm 0.45^{A}$ & $89.68 \pm 13.19^{a}$ \\
\hline & 100 & $1033 \pm 7.00^{\mathrm{B}}$ & $2106.73 \pm 1.12^{A}$ & $417.59 \pm 0.70^{B}$ & $64.62 \pm 11.87^{b}$ \\
\hline & 200 & $1145 \pm 9.00^{A}$ & $2030.48 \pm 29.69^{B}$ & $348.68 \pm 0.01^{\mathrm{C}}$ & $54.07 \pm 1.32^{\mathrm{b}}$ \\
\hline & $\bar{\chi}$ & 1009 & 2071.49 & 446.31 & 69.46 \\
\hline & LSD & 31.30 & 55.47 & 1.337 & 18.19 \\
\hline \multirow[t]{5}{*}{ Fourth } & 0 & $1258 \pm 11.00^{\mathrm{B}}$ & $1520.91 \pm 8.54$ & $835.89 \pm 5.11^{A}$ & $112.80 \pm 0.79^{A}$ \\
\hline & 100 & $1312 \pm 12.00^{\mathrm{B}}$ & $1529.27 \pm 7.84$ & $667.99 \pm 0.06^{\mathrm{C}}$ & $26.81 \pm 1.58^{C}$ \\
\hline & 200 & $1393 \pm 14.00^{A}$ & $1504.00 \pm 37.29$ & $749.61 \pm 1.34^{B}$ & $42.58 \pm 1.58^{\mathrm{B}}$ \\
\hline & $\bar{\chi}$ & 1321 & 1518.06 & 751.16 & 60.73 \\
\hline & LSD & 55.38 & NS & 10.056 & 6.164 \\
\hline \multirow[t]{5}{*}{ Fifth } & 0 & $1125 \pm 19.00^{c}$ & $1852.06 \pm 3.60^{B}$ & $856.71 \pm 4.0^{\mathrm{A}}$ & $94.66 \pm 3.74^{A}$ \\
\hline & 100 & $1307 \pm 17.00^{\mathrm{B}}$ & $1939.89 \pm 6.55^{A}$ & $772.92 \pm 14.5^{\mathrm{B}}$ & $54.19 \pm 3.05^{\mathrm{B}}$ \\
\hline & 200 & $1426 \pm 21.00^{A}$ & $1763.85 \pm 6.63^{c}$ & $753.42 \pm 2.12^{\mathrm{B}}$ & $33.67 \pm 2.12^{\mathrm{C}}$ \\
\hline & $\bar{\chi}$ & 1286 & 1851.93 & 794.35 & 60.84 \\
\hline & LSD & 84.73 & 12.34 & 30.48 & 12.38 \\
\hline \multirow[t]{6}{*}{ Sixth } & 0 & $1210 \pm 13.00^{\mathrm{B}}$ & $2103.58 \pm 13.27^{B}$ & $962.70 \pm 2.77^{A}$ & $102.93 \pm 7.25$ \\
\hline & 100 & $1335 \pm 15.00^{A}$ & $2149.91 \pm 6.07^{A}$ & $811.52 \pm 0.35^{\mathrm{B}}$ & $108.73 \pm 15.95$ \\
\hline & 200 & $1386 \pm 18.00^{\mathrm{A}}$ & $2145.52 \pm 0.12^{A}$ & $762.52 \pm 0.85^{C}$ & $95.63 \pm 0.92$ \\
\hline & $\bar{\chi}$ & 1310 & 2133.00 & 845.58 & 102.43 \\
\hline & LSD & 69.55 & 37.24 & 7.370 & NS \\
\hline & 0 & 1057 & 1931.56 & 841.35 & 93.32 \\
\hline \multirow[t]{2}{*}{ Average } & 100 & 1304 & 1962.51 & 675.79 & 51.55 \\
\hline & 200 & 1401 & 1915.67 & 680.34 & 46.38 \\
\hline Average & & 1254 & 1936.58 & 732.49 & 63.75 \\
\hline
\end{tabular}

*Mean values $\pm S D$ followed by the same letter within each column do not differ significantly at $p \leq 0.05$ (a) and $p \leq 0.01$ (A) according to the LSD test; NS: Not significant

capacity of stinging nettle strongly depended on harvest period. The lowest values at 0,100 and $200 \mathrm{~kg} \mathrm{~N} \mathrm{ha}^{-1}$ were recorded after the fourth harvest $(1520.91,1529.27$ and

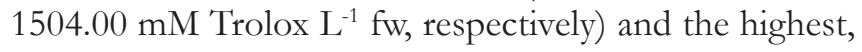
the same as total phenols, after the last harvest (2103.58, 2149.91 and $2145.52 \mathrm{mM}$ Trolox $\mathrm{L}^{-1} \mathrm{fw}$, respectively). Biesiada et al. (2009) claim that the harvest term had a more significant effect on antioxidant activity of raw material than form and dose of nitrogen fertilization. Raw material of nettle collected in May had higher antioxidant capacity compared to the harvest term in July. According to Biesiada et al. (2010) in two year old plants the lowest antioxidant activity was determined after the

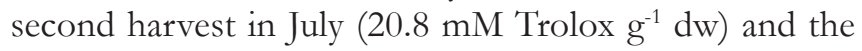
highest after the third harvest in September (37.9 Trolox $\mathrm{g}^{-1} \mathrm{dw}$ ). Otles and Yalcin (2012) pointed up that the highest antioxidant activity in nettle was recorded in rhizomes, then stems and leaves. Additionally, antioxidant activity differed significantly depending on the location from which the wild nettle was harvested.

The phenolic compounds contribute to the antioxidant activity of plants (Özkan et al., 2011), however it can be correlated with a high content of other chemical compounds, such as sugars or ascorbic acid (Kähkönen et al., 1999). Total phenols were in the range from 348.68

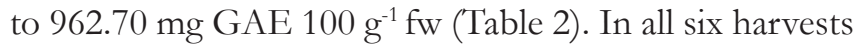
inverse relationship between nitrogen fertilization and total phenolic compounds were determined. Therefore, the highest phenolic values were measured in the absence of

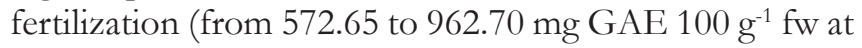
$0 \mathrm{~kg} \mathrm{~N} \mathrm{ha}{ }^{-1}$ ). Regardless of the nitrogen doses, the lowest 
average value of total phenols were recorded after the third harvest (446.31 mg GAE $100 \mathrm{~g}^{-1} \mathrm{fw}$ ) and the highest, as well as antioxidant capacity and ascorbic acid, after the last harvest (845.58 mg GAE $100 \mathrm{~g}^{-1} \mathrm{fw}$ ). Conversely, according to the results of Biesiada et al. (2009) phenolic compounds in the extracts of stinging nettle leaves were about $30 \%$ higher in May than in July.

Ascorbic acid (vitamin C) is known as an essential vitamin that in the organism must be taken by food. Values of ascorbic acid in cultivated nettle ranged from 16.00 to $112.80 \mathrm{mg} 100 \mathrm{~g}^{-1} \mathrm{fw}$ (Table 2). The effect of nitrogen fertilization on content of ascorbic acid was statistically significant in all harvests, with the exception of the last harvest. Nitrogen fertilization had a negative effect on ascorbic acid content and the highest values were measured at $0 \mathrm{~kg} \mathrm{~N} \mathrm{ha}^{-1}$ (from 48.82 to $112.80 \mathrm{mg}$ $100 \mathrm{~g}^{-1} \mathrm{fw}$ ). Increased number of harvests resulted in an increase of ascorbic acid content and the lowest average value of this vitamin was recorded after the first harvest (36.70 mg $100 \mathrm{~g}^{-1} \mathrm{fw}$ ), while the highest after the sixth

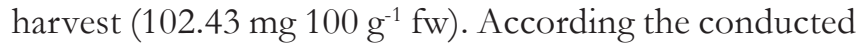
research cultivated nettle, besides minerals and phenols, is a valuable source of vitamin C (63.75 mg $\left.100 \mathrm{~g}^{-1} \mathrm{fw}\right)$. Comparatively, wild nettle contains smaller amounts of

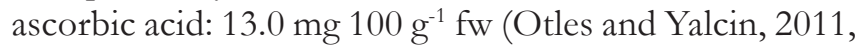

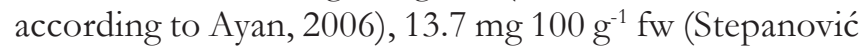
et al., 2009) and $36.40 \mathrm{mg} 100 \mathrm{~g}^{-1} \mathrm{fw}$ (Skalozubova and Reshetova, 2013).

\section{CONCLUSIONS}

The experiment proved that cultivated nettle is a valuable food resource in human nutrition, since is rich in minerals, especially iron, vitamin $C$, total phenols and has high antioxidant capacity. The obtained results indicated that higher doses of nitrogen fertilization (100 and $200 \mathrm{~kg} \mathrm{~N} \mathrm{ha}^{-1}$ ) resulted in higher amounts of crude protein, potassium and calcium. On the other hand, nitrogen fertilization reduced the content of dry matter, iron, total phenols and ascorbic acid, and also resulted with the accumulation of potentially harmful nitrates. Therefore, in order to achieve a desirable quality and chemical composition, fertilization with $100 \mathrm{~kg}$ $\mathrm{N} \mathrm{ha}^{-1}$ should be recommended in cultivation of stinging nettle in continental part of Croatia.

\section{AUTHOR CONTRIBUTIONS}

All authors contributed extensively to the work presented in this article. Sanja Radman carried out the experiment and acted as corresponding author. Ivanka Žutić, Nina Toth and Lepomir Čga contributed to the designing of the experiment and supervised development of work. Sanja Radman, Ivanka Žutić and Sanja Fabek wrote the paper. Jana Šic Žlabur, Božidar Benko and Sanja Fabek performed statistical analysis and helped in interpretation of data and discussion of results. All authors have read and approved the final manuscript.

\section{REFERENCES}

Ahangarpour, A., M. Mohammadian and M. Dianat. 2012. Antidiabetic effect of hydroalcholic Urtica dioica leaf extract in male rats with fructose-induced insulin resistance. Iran. J. Med. Sci. 37(3): 181.

Andualem, D., T. Negesse and A. Tolera. 2015. Biomass yield, chemical composition and in vitro organic matter digestibility of stinging nettle (Urtica simensis) from four locations at three stages of maturity. Livest. Res. Rural. Dev. 27(8): 1-8.

AOAC. 1995. Official Methods of Analysis. 16th ed., Vol. I. Association of Official Analytical Chemists, Arlington, USA.

AOAC. 2002. Official Method of Analysis. 17th ed., Vol. I. Association of Official Analytical Chemists, Arlington, USA.

Bacci, L., S. Baronti, S. Predieri and N. Di Virgilio. 2009. Fiber yield and quality of fiber nettle (Urtica dioica L.) cultivated in Italy. Ind. Crops Prod. 29: 480-484.

Başgel, S. and S. B. Erdemoğlu. 2006. Determination of mineral and trace elements in some medicinal herbs and their infusions consumed in Turkey. Sci. Total Environ. 359(1): 82-89.

Bergmann, W. 1992. Nutritional Disorders of Plants. Gustav Fischer Verlag Jena, Stuttgart, New York, Pp. 117-150.

Biesiada, A., A. Kucharska, A. Sokół-Łętowska and A. Kuś. 2010. Effect of the age of plantation and harvest term on chemical composition and antioxidant activity of stinging nettle (Urtica dioica L.). Ecol. Chem. Eng. 17(9): 1061-1068.

Biesiada, A. and E. Woloszczak. 2007. The effect of method of plantation establishing on yield and chlorophyll concentration of stinging nettle (Urtica dioica L.) in the first year of cultivation. Herb. Pol. 53(3): 85-89.

Biesiada, A., E. Woloszczak, A. Sokół-Lętowska, A. Z. Kucharska and A. Nawirska-Olszańska. 2009. The effect of nitrogen form and dose on yield, chemical composition and antioxidant activity of stinging nettle (Urtica dioica L.). Herb. Pol. 55(3): 84-93.

Bisht, S., S. Bhandari and N. S. Bisht. 2012. Urtica dioica (L): An undervalued, economically important plant. Agric. Sci. Res. J. 2: $250-252$.

Cárdenas-Navarro, R., S. Adamowicz and P. Robin. 1999. Nitrate accumulation in plants: A role of water. J. Exp. Bot. 50: 613-624.

Ćustić, M., M. Poljak, L. Čoga, T. Ćosić, N. Toth and M. Pecina. 2003. The influence of organic and mineral fertilization on nutrient status, nitrate accumulation, and yield of head chicory. Plant Soil Environ. 49: 218-222.

Di Virgilio, N., E. G. Papazoglou, Z. Jankauskiene, S. Di Lonardo, M. Praczyk and K. Wielgusz. 2015. The potential of stinging nettle (Urtica dioica L.) as a crop with multiple uses. Indian Crops Prod. 68: 42-49.

EFSA. 2008. Opinion of the scientific panel on contaminants in the food chain on a request from the European commission to perform a scientific risk assessment on nitrate in vegetables. EFSA J. 689: 1-79.

Fabek, S., N. Toth, I. Radojčić Redovniković, M. Herak Ćustić, B. Benko and I. Žutić. 2012. The effect of nitrogen fertilization 
on nitrate accumulation and the content of minerals and glucosinolates in broccoli cultivars. Food Technol. Biotechnol. 50(2): 183-191.

Grevsen, K., X. C. Frette and L. P. Christensen. 2008. Concentration and composition of flavonol glycosides and phenolic acids in aerial parts of stinging nettle (Urtica dioica L.) are affected by nitrogen fertilization and by harvest time. Eur. J. Hortic. Sci. 73(1): 20-27.

Guil-Guerrero, J. L., M. M. Rebolloso-Fuentes and M. E. Torija Isasa. 2003. Fatty acids and carotenoids from stinging nettle (Urtica dioica L.). J. Food Compost. Anal. 16(2): 111-119.

Gülçin, I., I., Ö. İ. Küfrevioğlu, M. Oktay and M. E. Büyükokuroǧlu. 2004. Antioxidant, antimicrobial, antiulcer and analgesic activities of nettle (Urtica dioica L.). J. Ethno pharmacol. 90(2): 205-215.

HRN ISO 11465. 2004. Gravimetric Method: Determination of Dry Matter and Water Content on a Mass Basis. Croatian Standard Institute, Zagreb.

HRN ISO 13878. 2004. Elementary Analysis: Determination of Total Nitrogen Content with Dry Combustion. Croatian Standard Institute, Zagreb.

HRN ISO 10304-1. 1998. Water Quality: Determination of Fluorides, Chlorides, Nitrites, Orthophospathes, Bromides, Nitrates and Sulfates with lon Liquid Chromatography - Part 1. Croatian Standard Institute, Zagreb.

Kähkönen, M. P., A. I. Hopia, H. J. Vuorela, J. P. Rauha, K. Pihlaja, T. S. Kujala and M. Heinonen. 1999. Antioxidant activity of plant extracts containing phenolic compounds. J. Agric. Food Chem. 47(10): 3954-3962.

Kaya, A. and O. Aydın. 2009. An experimental study on drying kinetics of some herbal leaves. Energy Conv. Man. 50(1): 118-124.

Koczka, N., D. Petersz and E. Stefanovits-Banyai. 2015. Total phenol content and antioxidant capacity (FRAP) of Urtica dioica L. Leaf extracts. Acta Hortic. 1099: 207-210.

Kukrić, Z. Z., L. N. Topalić-Trivunović, B. M. Kukavica, S. B. Matoš, S. S. Pavičić, M. M. Boroja and A. V. Savić. 2012. Characterization of antioxidant and antimicrobial activities of nettle leaves (Urtica dioica L.). Acta Period. Technol. 43: 257-272.

Miller, N. J., A.T. Diplock, C. Rice-Evans, M. J. Davies, V. Gopinathan and A. Milner. 1993. A novel method for measuring antioxidant capacity and its application to monitoring the antioxidant status in premature neonates. Clin. Sci. 84: 407-412.

Podsędek, A. 2007. Natural antioxidants and antioxidant capacity of Brassica vegetables: A review. LWT-Food Sci. Technol. 40: 1-11.

Otles, S. and B. Yalcin. 2012. Phenolic compounds analysis of root, stalk and leaves of nettle. ScientificWorldJournal. 2012: 1-12.

Ough, C. S. and M. A. Amerine. 1988. Methods for Analysis of Musts and Wines. J. Wiley \& Sons, Washington, DC.

Özkan, A., Ö. Yumrutaş, S. D. Saygideğer and M. Kulak. 2011. Evaluation of antioxidant activities and phenolic contents of some edible and medicinal plants from Turkey's flora. Adv. Environ. Biol. 5(2): 231-236.

Ozyurt, D., B. Demirata and R. Apak. 2007. Determination of total antioxidant capacity by a new spectrophotometric method based on Ce(IV) reducing capacity measurement. Talanta. 71(3): 11551165.

Radman, S., S. Fabek, I. Žutić, B. Benko and N. Toth. 2014. Stinging nettle cultivation in floating hydropon. Contemp Agric. 63(3): 215-223.

Re, R., N. Pellegrini, A. Proteggente, A. Pannala, M. Yang and C. A. Rice-Evans. 1999. Antioxidant activity applying an improved ABTS radical cation decolorization assay. Free Radic. Biol. Med. 26(9-10): 1231-1237.

Rutto, L. K., M. S. Ansari and M. Brandt. 2012. Biomass yield and dry matter partitioning in greenhouse-grown stinging nettle under different fertilization regimes. Hortic. Technol. 22(6): 751-756.

Rutto, L., X. Yixiang, E. Ramirez and M. Brandt. 2013. Mineral properties and dietary value of raw and processed stinging nettle (Urtica dioica L.). Int. J. Food Sci. 2013: 1-9.

Santamaria, P. 2006. Nitrate in vegetables: Toxicity, content, intake and EC regulation. J. Sci. Food Agric. 86: 10-17.

SAS Institute. SAS ${ } / S T A T$ User's Guide. Version 9.3. Cary, NC, USA: SAS Publishing; 2010.

Shimada, Y. and S. Ko. 2004. Nitrate in vegetables. Chugoku Gakuen J. 3: 7-10.

Skalozubova, T. A. and V. O. Reshetova. 2013. Leaves of common nettle (Urtica dioica L.) as a source of ascorbic acid (vitamin C). World Appl. Sci. J. 28(2): 250-253.

Stepanović, B., D. Radanović, I. Turšić, N. Nemčević and J. Ivanec. 2009. Cultivation of Medicinal and Aromatic Plants. Jan Spider, Pitomača (in Croatian).

Upton, R. 2013. Stinging nettles leaf (Urtica dioica L.): Extraordinary vegetable medicine. J. Herb. Med. 3(1): 9-38.

Vajić, B. 1964. Food, Determination of the Main Ingredients, University of Zagreb, Zagreb (in Croatian).

Weiss, F. 1993. Effects of varied nitrogen fertilization and cutting treatments on the development and yield components of cultivated stinging nettles. Acta Hortic. 331: 137-144.

Yıldız, L., K. Sözgen Başkan, E. Tütem and R. Apak. 2008. Combined HPLC-CUPRAC (cupric ion reducing antioxidant capacity) assay of parsley, celery leaves, and nettle. Talanta. 77 : 304-313. 